CHAPTER 24:

\title{
A Moral Perspective on Citizenship Education and on IEA's International Civic and Citizenship Education Studies
}

\section{Wiel Veugelers}

\begin{abstract}
Citizenship education can be conceptualized within different frameworks or perspectives about the meaning of citizenship. These differences become more important when the focus is on educational policy and practice. The chapter first discusses a national concept of citizenship and then the concept of global citizenship. This chapter conceptualizes three different types of national citizenship: adapted, individualized, and critical-democratic. Research into global citizenship also shows three types: an open global citizenship with an emphasis on cultural openness; a moral global citizenship focusing on the well-being of humanity; and a social-political global citizenship aimed at greater social justice. These distinctions emphasize the influence of globalization on the articulation of civic and citizenship education. Global citizenship focuses on human rights principles as moral guidelines for improving the world; national citizenship focuses on strengthening national culture. This chapter demonstrates the relevance of moral values for civic and citizenship education. It also presents suggestions for including moral values in the conceptual framework of the IEA's International Civic and Citizenship Education Study (ICCS). To that end, it concludes by suggesting a new definition of education for citizenship.
\end{abstract}

\section{Introduction}

The concept of citizenship appears in policy, in research, and in social practice and has become central in contemporary policy discussion. Traditionally citizenship was only linked to the political domain of one's country (Isin and Turner 2002); in recent decades the concept has been "broadened" and "deepened" (Veugelers 2011a). It is "broadened" because the concept is no longer linked only to the nation state, but also to regional identities such as the European Union and even to the world as a whole. By "deepened" we mean that the concept of citizenship pertains not only to the political level of society but also in the social and cultural domain. This deepening makes citizenship a normative and therefore a contested concept. In this process of deepening, the concept of citizenship becomes linked to moral development. The concepts of citizenship and of citizenship education, when viewed in their global perspectives, have diverse meanings (Veugelers 2011b; Oxley and Morris 2013; Goren and Yemini 2017). This is partly because they express the different underlying moral values that characterize different societies.

The deepened concept of citizenship defines the kind of person society desires not only at the political level but also on the social and cultural levels. It is a paradox that this spread in the concept of citizenship and attempts to strengthen citizenship education policy is taking place in a period when there is a focus on a small and restrained government that leaves many activities to market forces. However, there is a belief within contemporary pluralist societies that ideological institutions have lost much of their impact, and citizenship policy cannot be left to the market. Citizenship should have a robust and powerful presence in education. Many countries are reconsidering their policies on citizenship education and extending it into the social and cultural domain (Banks 2017; Schulz et al. 2018; Veugelers et al. 2017; Garcia et al. 2017; Kennedy et al. 2018). Likewise, the number of countries participating in the cycles of International Association for the Evaluation of Educational Achievement (IEA) citizenship studies gives evidence of the extent of interest in comparisons among countries with respect to policies, results, and potential reforms of citizenship education.

Wiel Veugelers, University of Humanistic Studies, Utrecht, the Netherlands email: w.veugelers@uvh.nl

(C) IEA International Association for the Evaluation of Educational Achievement 2021 


\section{A Perspective on Citizenship Education from Research and Theory}

Citizenship education has become an important topic in the policy of many countries, and many researchers have started empirical projects. As research on citizenship education is becoming a solid academic field it is interesting to analyze the disciplines from which these researchers come and the conceptual frameworks for their work.

We present a short "genealogy" of the academic field of citizenship education over the past five decades. Traditionally, the academic field of citizenship studies was part of the discipline of political science studying political socialization. In the post-war period, Marshall (1964) shaped modern thinking about political systems and institutions along with rights and duties. Sociologists like Isin and Turner (2002) and Bourdieu (1984) entered the field, making the connection between the political arena and civil society stronger. At that period the focus in the sociology of education was on the extent to which the political socialization process resulted in the reproduction of social and political power relations and positions. Critical pedagogy added a transformative perspective and was based on the educational work of Freire (1985, reviewed by Veugelers 2017a). It was extended by Giroux (1989) into a more comprehensive theory of building democracy through education. This made citizenship more dynamic and transformative. Political psychologists like Torney-Purta (2002) and Haste (2004) drew attention to empirical studies of the cognitive and affective processes involved in youngsters' social and political development. Philosophers, McLaughlin (1992), Nussbaum (1997), and Crick (1999), entered the debate about what citizenship, democracy, and participation mean, and how education can contribute to citizenship development. This was followed by the political philosophy of Mouffe (2005) discussing contradictions in citizenship and in democracy.

Citizenship education also became more central to policy and practice, and other disciplines joined the debate. Social studies researchers focused on curriculum content (Kerr 1999), on classroom activities like deliberation (Parker 2003), and on teaching about controversial issues (Hess 2009). Multicultural educators (Banks 2004) argued for attention to diversity. At the same time, human rights scholars (Osler and Starkey 2010) focused attention on individual rights and common values. Within the field of educational studies and pedagogy, Westheimer and Kahne (2004) investigated service learning taking place during civic education experiences and Biesta (2011) explored "subjectification," becoming a subject, in relationship to citizenship education and emphasized personal signification instead of socialization.

School effectiveness research was one contributor to the initiation of the first IEA civic education study (Torney et al. 1975) and then to the IEA Civic Education Study (CIVED) conducted in 1999 (reported in Torney-Purta et al. 2001). Of even more importance in initiating that study was the desire by the Eastern European countries that had recently become independent of the Soviet Union to better understand processes of civic education in democracy. The questionnaires measuring students' attitudes and participation were formulated by cross-national and crossdisciplinary groups of scholars and were repeated and extended in the International Civic and Citizenship Education Study (ICCS) (Schultz et al. 2010; 2017). Understanding the impact of these three large-scale international assessments of civic education is the primary subject of the chapters in this volume and frames this chapter as well.

At about the same time these studies were being published, an interdisciplinary group of scholars was working in the realm of moral education. These included Haste (2004), Althof and Berkowitz (2008), and Oser and Veugelers (2008), who were linking morality with society and the political domain. They emphasized that moral values are not abstract notions but embedded in societal contexts and political power relations. Post-colonial studies (Andreotti 2011; Torres 2017) went beyond a Western perspective on the conceptualization of citizenship and of citizenship education and joined the attempts of many scholars to emphasize social justice. A specific Asian perspective 
has been examined by scholars like Kennedy et al. (2010) and Sim (2011). They argued that an Asian perspective places more emphasis on attachment to local and regional traditions. The concern for sustainability has also become part of citizenship: the citizen and their surroundings should become not only democratic but also sustainable into the future (Gaudelli 2016). All these researchers, focusing on a particular knowledge base and their own epistemological perspective, have contributed to citizenship education studies. It is now a dynamic field framed by several, sometimes diverging, social, moral, cultural, and political perspectives.

This overview demonstrates that as citizenship education became the subject of policy and research some distinctions were made in the underlying conceptualization. We first will demonstrate this for more national aspects of citizenship and then for aspects of global citizenship. National citizenship is more inward-directed and global citizenship more outward-directed. However, examining practice informed by research identifies further complexity.

\section{Three Orientations Toward the Goals of Citizenship Education}

In our empirical research in the Netherlands among teachers, students, and parents, we found three orientations to citizenship that give special attention to moral values. In several research projects (with both quantitative and qualitative instruments), we asked teachers, students, and parents about which educational goals relating to moral values and society they found important. Most of the research was in secondary schools, but also some in primary schools. We conducted a representative survey among Dutch secondary school teachers. We also performed case studies in schools using surveys, interviews, panels, and observations to collect data from teachers, students, and parents. Statistical analyses of the survey among teachers showed three clusters of teachers supporting specific but different educational goals: discipline, autonomy, and social involvement (Leenders et al. 2008a; 2008b; 2012). More conceptual explorations of these clusters are found in Veugelers (2007; 2017b).

(1) Discipline and Norms: teachers in this cluster emphasize goals promoted by the educational movement called "character education" (Lickona 1991). This approach to moral education promotes students following norms of good behaviour. Educators teach students how they should behave.

(2) Autonomy: teachers in this cluster refer to personal empowerment and students formulating their own opinions. These goals are central in the moral development tradition of Kohlberg (Power et al. 1989) but also in the structural sociology of Giddens (1990), which emphasizes "agency." Autonomy can be defined as making free choices that give meaning to life.

(3) Social Involvement: teachers in this cluster support a broad spectrum of social goals, from empathy as social psychologists define it, to a social justice-based solidarity and commitment to combat inequality in society. Looking at this in a broader context, different orientations exist within social involvement: the justice approach of Rawls (1971) and Kohlberg, the concept of care of Noddings (2002), and the sense of empowerment expressed by the Brazilian pedagogue Freire (1985). Social involvement can vary greatly in its political orientation and in the articulation of the moral values involved.

Note that these results are similar to the three teacher profiles based on civic education aims that were identified by Reichert and Torney-Purta (2019) using ICCS 2009 data from 12 countries, not including the Netherlands. 


\section{Three Profiles in the Goals and Aims of Nationally Based Citizenship}

Further analyzing our data (with person-centred factor analyses), we were also able to construct three profiles of citizenship, expressing different orientations in teachers' goals and educational practice (we have called them types) (Leenders et al. 2008a).

(1) The first type is adaptive citizenship. Discipline and some types of social involvement are important to individuals who fall into this profile. This is a moral commitment to others in one's school, family, and community. There is considerable transmission of adaptive values and attention to standards and norms as part of education. Some attempts to inculcate moral values are direct and others are embedded in assumptions that some refer to as part of an implicit or hidden curriculum.

(2) The second type is individualized citizenship. Autonomy is very important and discipline fairly important. There is a focus on personal development and freedom as expressions of moral values such as autonomy. Less importance is placed on social involvement. The social context and issues with moral dimensions outside the school receive little attention. Educators try to develop students' sense of independence and critical thinking ability. Moral values are viewed as a matter of personal choice and of less concern to the school.

(3) The third type is critical-democratic citizenship. There is a belief that social involvement and autonomy are very important and discipline less important. The focus is on critical analysis of issues and engagement with the common good. This can lead to encouraging action against inequality, for example. This perspective tries to balance the moral values of autonomy with social concern. In education there is a focus on appreciating diversity and living in harmony but also on active student participation in dialogues with those who have different backgrounds or opinions. Cooperative and inquiry-oriented learning is often an approach. Attention is given to critical reflection on social values.

We have defined the types of citizenship and corresponding practical classroom interpretations found in our empirical studies of teachers and our review of the literature as ideal-types. In people's views and in educational practice we find many hybrid forms combining these types of citizenship and types of citizenship education. In their educational philosophy and in their practice most people strike a balance between broader orientations like autonomy and social involvement. This typology demonstrates that different orientations to the moral and political nature of citizenship and citizenship education exist. One does not need to label one as superior to others, they each are linked to broader philosophical and political ideas. As important, it also shows that school leaders and teachers make choices in their educational goals and in their educational practice. Different aspects of citizenship will be important in specific countries and under specific circumstances. These are among the reasons for national differences in the civic education studies' results. Our empirical studies in the Netherlands show that many teachers like critical-democratic citizenship education, but it is less frequently seen in practice than a more adaptive citizenship. Individualized citizenship education is not very popular among teachers but it is strongly embedded in schools through systems of individual assessment, comparison, selection, and tracking of students. The educational guidance given by teachers is strongly directed at the school career and well-being of the individual student. This school practice reinforces an individualized citizenship (Veugelers 2017b).

\section{Three Profiles in the Goals and Aims of Global Citizenship}

The concept of citizenship has been broadened from the national to the global level in recent decades. The process of globalization is influencing civic and citizenship education. Most definitions of globalization emphasize the links between different parts of the world. The content of globalization is ideologically charged and differs in different world regions and within countries (Roderik 2011). In parallel with national citizenship we also studied how teachers 
and researchers are defining and using the concept of global citizenship. We explored different meanings and practices that instantiate concepts of global citizenship in education (Veugelers 2011b). We analyzed literature and conducted interviews with secondary school teachers about their concepts and practices. Based on the literature review and the interviews we identified three types of global citizenship. These are still under development without empirical support to the extent of that in previous section.

(1) An open global citizenship education focuses on knowledge about and openness to other cultures. Many people refer to an open global citizenship as a neo-liberal mix of cultural diversity and market economy. It is a quite popular notion, however it is difficult to find scholars who clearly express such a liberal view on global citizenship.

(2) A moral global citizenship education has three pillars:

a) Creating possibilities for each human being to develop his or her capabilities (Nussbaum 1997).

b) A concern for the planet and all its inhabitants. This includes a focus on environmental sustainability; it challenges each human being to take moral responsibility and to contribute through concrete actions (Gaudelli 2016).

c) Open communication in which everyone can participate. This is often called "cosmopolitanism" and refers to the Greek idea of the polis (Appiah 2005; Hansen 2011). This dimension of global citizenship is especially linked with attention to human rights as a moral force.

(3) A social-political global citizenship addresses unequal power relations and is devoted to social justice and a corresponding political change. Proponents of this view criticize moral global citizenship as not taking political power relations into account. Social-political global citizenship is committed to combatting inequality and creating a more just society. This position can be found in the work of critical pedagogy, in particular Paulo Freire (1985), in political philosophy (Mouffe 2005; 2017), and in post-colonialist thinking (Andreotti 2011).

There is a sense of hierarchy in this typology. Moral global citizenship adds a concern for each human being, humanity, and the planet to open global citizenship. The social-political global citizenship approach not only challenges individuals to become moral as global citizens, but also pushes for political change, empowerment, equality, and social justice to realize such a moral world for all.

As in the typology for national citizenship, these different types of global citizenship are linked with educational practices. In our research, many Dutch teachers said that they focus on a moral global citizenship. They encourage students to engage in dialogues, to support human rights, and to commit to building a better world. However, teachers try to avoid overt politics. Addressing injustice and transformation of power relations is not their approach to citizenship education. Their argument is that they should be neutral. They don't really address social problems or put these in a political framework (Veugelers 2011b).

Many recent publications focus on what we have called a "moral global citizenship." For example, Hansen (2011) argues for a cosmopolitan education that includes a space in which each person has the opportunity to become part of a dialogue. A typical example of a moral global citizenship education perspective is the book by Gaudelli, Global Citizenship Education: Everyday transcendence. He acknowledges that there are concerns about the rapid integration of the world (hyper-globalization), particularly regarding economic and environmental consequences. He also formulates the following as a long-term educational goal: "An aspirational sense of being human as a universal condition coupled with openness to the plurality of people and their environs" (Gaudelli 2016, p. 6). 
We find a political view on global citizenship in the work by Andreotti (2011) and Torres (2017) that is more transformational than authors who promote moral global citizenship. Political power relationships and criticism of a neo-liberal market mode of globalization are included. Taking an empowerment perspective, Torres (2017) emphasizes solidarity. Referring to UNESCO-policy, he argues for human rights as part of global citizenship and further criticises the neo-liberal economic market orientation in globalization.

The political-philosopher Mouffe (2017) proposes that the world should be considered as multipolar, posing a challenge to Western domination. This raises the question about how to create a more multipolar world order and a corresponding moral philosophy. Such a balance could be sought through a stronger connection of human rights and democracy with economic equality, social justice, equal power relations, and respect for different cultures. This emphasis on social-political global citizenship, in which the personal and the social, cultural, moral, and political aspects are connected, is a challenging goal for future academic, policy, and actionoriented work. Similar points could be made about nationally oriented citizenship.

Although national and global types of citizenship are certainly connected, it can be argued that domestically oriented civic education orients the student to institutions like the nation state and to rights contained in national documents such as constitutions. Global citizenship has a broader scope and refers to international documents (such as the Universal Declaration of Human Rights) and to organizations that cross national borders. A crucial difference between a national and a global citizenship is that national citizenship focuses on a specific community and a global citizenship on the whole planet (the world community). In both national and global citizenship frameworks issues of morality and politics should be crucial.

For studying citizenship education different academic disciplines are necessary: political sciences and sociology for ideas and practices of citizenship; ethics for analyzing normative positions; pedagogy for formulating educational goals; educational studies for analyzing school systems, teachers' actions, school climate, and student outcomes; and psychology to study the developmental processes of emerging moral orientations in students and their interactions with each other, the teachers, and the moral values embedded in their education. A moral education perspective on citizenship can integrate these different scientific domains.

\section{A Moral Education Perspective on International Civic and Citizenship Education Studies}

Based on this overview of different articulations of citizenship and global citizenship education we now analyze what a moral perspective on citizenship studies such as ICCS reveals and address four issues:

\section{The importance of attitudes in citizenship}

People can have knowledge about democracy, and they can have democratic skills, but it is crucial for them to have attitudes supportive of rights for others and principles of participatory democracy if they are to act in a democratic way. Intentions and concrete behaviour are essential elements of citizenship in practice. Of course, it is important for citizens to have the relevant knowledge and to master the skills, but the attitude component makes a real difference. Psychological concepts like sense of involvement (Oser and Veugelers 2008) and engagement (De Groot et al. 2014) are also part of citizenship. Moral values are expressed in such attitudes (Haste 2004). The IEA studies of civic education (starting in the 1970s) have paid substantial attention to attitudes. In all these studies citizenship attitudes formed a substantial part of the conceptual framework and were operationalized in the measurement instruments. A recent review by Knowles et al. (2018) examined 100 articles reporting secondary analysis of IEA's civic education data published since 2000 and found that a very large majority focused on the 
attitudinal and participatory data (not the civic knowledge scores). In particular, many authors from Belgium (Flemish), Italy, and Sweden were represented. The potential value of the findings of these studies for illuminating moral education issues should be explored as it is often implicit rather than explicit.

\section{Subjectification as an issue}

Dialogue plays a vital role in a social-constructivist perspective on learning as students explore meaning in the social world and develop attitudes and moral values (Veugelers 2019a). Biesta (2011) speaks of subjectification, which is not sufficiently captured by the term socialization. What is missing is the personal articulation: the individual student interprets concepts in a subjective fashion based on their own experience and through dialogue with others. Paying attention to subjectification in education is according to Joris and Agirdag (2019) at odds with a strong focus on goals and prescribed learning outcomes. They criticize the ICCS research from this perspective. Joris and Agirdag (2019, p. 287) conclude: "Our analysis shows that the qualification and socialization functions are dominantly validated in all aspects of the study, whilst there is only marginal attention to subjectification. This implies that ICCS misses an important potential to document and/or promote pupils becoming autonomous and critical democratic citizens, whilst this is often considered a central aim of citizenship education by policymakers, practitioners and teachers."

The arguments made by Joris and Agirdag make us aware of the relevance of individuals' construction of meaning. This suggests conducting research to show how students develop personal narratives relating themselves to citizenship (see, for example, De Groot et al. 2014). We recognize that quantitative research methods that are dominant in the IEA civic education studies cannot catch the concrete personal meanings of concepts and actions for each student. The IEA civic education studies' leaders are aware of this and have encouraged follow-up research projects incorporating more qualitative as well as quantitative approaches. The country chapters in this book present some of those studies.

\section{The meaning of democratic citizenship}

All nations recognize citizenship qualifications and have a more or less explicit citizenship policy related to a more or less formal curriculum of citizenship education. Nations have political regimes, ranging from authoritarian to democratic, and within democracy there are different articulations. So all nations have an idea of citizenship and have a practice of citizenship education. From an academic perspective it would be interesting to be able to inquire in all nations about different concepts of political regimes and citizenship in order to have a broad perspective for understanding different kinds of citizenship. Now ICCS focuses on aspects of democracy like elections, freedom of speech, and political representation. It is understandable that only regimes that have the kind of democracy based on these principles join the ICCS studies. Of course, it would be very difficult to do research on citizenship in non-democratic countries. In reality ICCS is a study not of citizenship but of democratic citizenship.

In the Latin America study that is part of ICCS there are some questions about dictatorship. When asked if people would like to have a dictatorship most people say no, however when asked about a dictatorship that has brought economic prosperity, many people have fewer problems with it. It would be interesting to include questions that challenge the notion of democracy in the general ICCS-questionnaire. It might be helpful to enhance the set of questions about what is good and bad for democracy (currently in the general ICCS questionnaires) in order to focus on a wider range of threats to democracy. Presently included are questions about whether one company owning all the newspapers is good or bad for democracy and a similar question about leaders appointing members of their own families to government positions. It is important to realize that democracy is a moral concept. It includes ideas about the way to organize society. 
One of the good things about democracy is that it supports research about the political system and citizens' opinions. Joining ICCS studies can be thought of as a kind of support for democratic openness. This point is also made in some country chapters in this volume.

\section{Social and cultural dimensions of citizenship}

The beginning of this chapter spoke about deepening the concept of citizenship. Not only is the political domain relevant, but also the social and cultural. It is about how people live together. It focuses at the same time on dealing with social and cultural differences and on what bonds people: on what keeps society together, on common moral values, and on norms and traditions. This bonding is in fact specific for each country. Each country has its own history and culture, and its own specific articulations of moral values. Countries can differ in how much they stress their own cultural tradition, expect individuals today to adapt to an "older" national culture and emphasize the homogeneity of it.

Countries can also show how their histories adapt to a mixture of traditions and some have a fluid social-cultural citizenship that is open to new influences. Inquiring about specific national articulations of citizenship is difficult in a comparative study. A study like ICCS looks for commonalities and compares countries on these specific variables. Countries also have opportunities to interpret and, in some cases, to add material in national questionnaires or other studies (as some country chapters in this volume discuss). This is not in any way an argument against comparative studies like ICCS but a suggestion to countries to give attention to the national context and to topics such as the moral education dimension when interpreting findings about commonalities and differences.

\section{The Moral Dimension in the Conceptual Framework of ICCS}

We now will analyze the assessment framework of the ICCS 2016 study referring to specific pages in Schulz et al. (2016). The authors speak of recent developments and persisting challenges (p. 3) and of broadening the scope of ICCS (p. 5). Recent developments mentioned are the financial crisis and environment; persisting challenges are the concepts of democracy and globalization. Broadening the scope of ICCS 2016 meant inclusion of three areas (p. 5): environmental sustainability, social interaction in school, and the use of new social media for civic engagement. We earlier mentioned the deepening of the concept of citizenship at the social and cultural level. Here even the environmental level is included. The second area, social interaction at school, can be seen as citizenship lived in the daily life of youngsters. School is a place where children can practice living together, hopefully in a democratic way. The third area, social media, extends political dialogues outside the traditional institutions and formal political dialogues, and includes informal ways of participation as part of civic life. This can be digital. These interactions between citizens are more informal and more related to students' daily lives. Other areas were identified that could be explored for future assessments including economic awareness and the role of morality in civic and citizenship education (p.6): "Concepts of morality and character are often involved in relation to outcomes of civic and citizenship education programmes ... many countries have moral education programmes."

There is some coverage of the moral perspective in the research questions for ICCS 2016 (pp. 7-8). The first research question is about educational programs; the second about outcomes of civic knowledge; the third is about engagement in society; the fourth about beliefs concerning civic issues such as democracy, citizenship, and society and about sense of identity; and, the fifth is about the organization of the school. The moral is embedded in research question four about students' beliefs and attitudes and to some extent in all the others: in particular the engagement in society (three) and the interactions in school (five). 
Chapter 2 of the assessment framework focuses on the civic and citizenship framework. Four content areas are distinguished: civic society and systems; civic principles; civic participation; and, civic identities (p.12). The student questionnaire includes affective-behavioural variables that reflect attitudes and engagement. The content domain of civic principles has the most explicit moral content. It consists of four sub-domains: equity, freedom, sense of community, and rule of law. In particular, the first three are moral values that are considered as important values in a democratic society. The fourth, rule of law, also includes relevant moral dimensions.

\section{Conclusions}

We can conclude that moral values play an important role in ICCS. They include different orientations of citizenship that were mentioned earlier: adaptive, individualized, and criticaldemocratic approaches. They are incorporated in concepts like justice, democracy, and freedom. Citizenship in a global and sustainable context stresses moral dimensions even more.

A moral values perspective makes clear that besides knowledge and skills, attitudes and concrete behaviour are important and that they express moral values. Moral values have always been embedded in ICCS, but during recent years they have been getting more explicit attention. This reflects developments in many countries that show that societies are searching for meaning and direction in terms of moral values. Should they return to a more adaptive orientation, celebrate an individual orientation, or take up a democratic orientation to social justice? The question is whether an appropriate balance between these three orientations can be found along with appropriate linkage between moral and political perspectives (Veugelers 2019a; 2019b).

In conclusion, we present an overarching definition that includes central concepts and attempts a synthesis of the moral and civic dimensions of the IEA's civic education studies. This definition defines the domain within a democratic framework but gives people the chance to make their own articulation,

Education for citizenship is about acquiring the abilities and attitudes necessary to participate in political and civic life (on local, national, and global levels); about relating to others, in particular people with different social, cultural, and ethnic backgrounds; and about concern for the sustainability of humanity, of the planet, and of democracy.

\section{References}

Andreotti, V. (2011). The political economy of global citizenship. Globalisation, Societies and Education, 9(3-4), 307-310.

Appiah, K. (2005). The ethics of identity. Princeton, NJ: Princeton University Press.

Banks, J. (2004). Diversity and citizenship education: global perspectives. San Francisco, CA: Jossey-Bass. Banks, J. (Ed.). (2017). Citizenship education and global migration. Washington, DC: AERA.

Biesta, G. (2011). Learning democracy in school and society. Rotterdam, the Netherlands: Sense Publishers. Bourdieu, P. (1984). Distinction. London, United Kingdom: Routledge.

Crick, B. (1999). The presuppositions of citizenship education. Journal of Philosophy of Education, 33(3), 337-352.

De Groot, I., Goodson, I., \& Veugelers, W. (2014). Dutch students' democratic narratives. Cambridge Journal of Education, 44(2), 271-292.

Durkheim, E. (1971[1923]). Moral education. New York, NY: Free Press.

Freire, P. (1985). The politics of education: Culture, power and liberation. South Hadley, MA: Bergin \& Garvey. Garcia, B., Sandoval, A., Trevino, E., Diazgranados, S., \& Perez, M. (Eds.). (2017). Civics and citizenship: theoretical models and experiences in Latin America. Rotterdam, the Netherlands: Sense Publishers.

Gaudelli, W. (2016). Global citizenship education: everyday transcendence. New York, NY: Routledge.

Giddens, A. (1990). The consequences of modernity. Cambridge, United Kingdom: Polity. 
Giroux, H. (1989). Schooling for democracy. London, United Kingdom: Routledge.

Goren, H. \& Yemini, M. (2017). Global citizenship redefined: a systematic review of empirical studies on global citizenship education. International Journal of Educational Research, 82, 170-183.

Hansen, D. (2011). The teacher and the world. New York, NY: Routledge.

Haste, H. (2004). Constructing the citizen. Political Psychology, 25 (3), 413-440.

Hess, D. (2009). Controversy in the classroom. New York, NY: Routledge.

Isin, E., \& Turner, B. (Eds). (2002). Handbook of citizenship studies. London, United Kingdom: Sage.

Joris, M., \& Agirdag, O. (2019). In search of good citizenship: a normative analysis of the International Civic and Citizenship Education Study (ICCS). European Journal of Education, 54(2), 287-298.

Kennedy, K., Lee, W. O., \& Grossman, D. L. (Eds.). (2018). Citizenship pedagogies in Asia and the Pacific. Dordrecht, the Netherlands: Springer.

Kerr, D. (1999). Citizenship education in the curriculum: an international review. The School Field, 3-4, 5-31.

Knowles, R., Torney-Purta, J., \& Barber, C. (2018). Enhancing citizenship learning with international comparative research: Analyses of IEA civic education datasets. Citizenship Teaching and Learning, 13, 7-30.

Leenders, H., Veugelers, W., \& De Kat, E. (2008a). Teachers' views on citizenship in secondary education in the Netherlands. Cambridge Journal of Education, 38(2), 155-170.

Leenders, H., Veugelers, W., \& De Kat, E. (2008b). Moral education and citizenship education at preuniversity schools. In F. Oser, \& W. Veugelers (Eds.), Getting involved: Global citizenship development and sources of moral values (pp. 57-74). Rotterdam, the Netherlands: SensePublishers.

Leenders, H., Veugelers, W., \& De Kat, E. (2012). Moral development and citizenship education in vocational schools. Education Research International, 2012(2). https://doi.org/10.1155/2012/901513

Lickona, T. (1991). Educating for character. New York, NY: Random House.

Marshall, T.H. (1964). Class, citizenship and social development. Chicago, IL: University of Chicago Press.

McLaughlin, T. (1992). Citizenship, diversity and education: a philosophical perspective. Journal of Moral Education, 21(3), 235-250

Mouffe, C. (2005). On the political. London, United Kingdom: Routledge.

Mouffe, C. (2017). For a left populism. London, United Kingdom: Verso.

Noddings, N. (2002). Educating moral people. New York, NY: Teachers College Press.

Nussbaum, M. (1997). Cultivating humanity. Cambridge, MA: Harvard University Press.

Oser, F., \& Veugelers, W. (Eds). (2008). Getting involved. Global citizenship development and sources of moral values. Rotterdam, the Netherlands: Sense Publishers.

Osler, A., \& Starkey, H. (2010). Teachers and human rights education. London, United Kingdom: IOE press.

Oxley, L., \& Morris, P. (2013). Global citizenship: a typology for distinguishing its multiple conceptions. British Journal of Educational Studies, 3, 301-325.

Parker, W. (2003). Teaching democracy. New York, NY: Teachers College Press.

Power, F. C., Higgins, A., \& Kohlberg, L. (1989). Lawrence Kohlberg's approach to moral education. New York, NY: Columbia University Press.

Rawls, J. (1971). A theory of justice. Cambridge, MA: Harvard University Press.

Reichert, F., \& Torney-Purta, J. (2019). A cross-national comparison of teachers' beliefs about the aims of civic education in 12 countries: A person-centered analysis. Teaching and Teacher Education, 77, 112-125. Roderik, D. (2011). The globalization paradox. New York, NY: Norton \& Company.

Sim, J. (2011). Social studies and citizenship for participation in Singapore: How one state seeks to influence its citizens. Oxford Review of Education, 37(6), 743-761.

Schulz, W., Ainley, J., Fraillon, J., Kerr, D., \& Losito, B. (2010). ICCS 2009 international report. Amsterdam, the Netherlands: International Association for the Evaluation of Educational Achievement (IEA).

Schulz, W., Ainley, J., Fraillon, J., Losito, B., \& Agrusti, G. (2016). International Civic and Citizenship Education Study 2016. Assessment framework. Cham, Switzerland: Springer.

Schulz, W., Ainley, J., Fraillon, J., Losito, B., Agrusti, G., \& Friedman, T. (2018). Becoming citizens in a changing world. IEA International Civic and Citizenship Education Study 2016 international report. Cham, Switzerland: Springer. https://doi.org/10.1007/978-3-319-73963-2 
Torney-Purta, J. (2002). Patterns in the civic knowledge, engagement, and attitudes of European Adolescents. The IEA Civic Education Study. European Journal of Education, 37(2), 129-141.

Torney, J., Oppenheim, A., \& Farnen, R. (1975). Civic education in ten countries: An empirical study. Stockholm, Sweden: Almqvist and Wiksell.

Torney-Purta, J., Lehmann, R., Oswald, H., \& Schulz, W. (2001). Citizenship and education in twenty-eight countries. Amsterdam, the Netherlands: International Association for the Evaluation of Educational Achievement (IEA).

Torres, C.A. (2017). Theoretical and empirical foundations of critical global citizenship education. New York, NY: Routledge.

Veugelers, W. (2007). Creating critical-democratic citizenship education: Empowering humanity and democracy in Dutch education. Compare, 37(1), 105-119.

Veugelers, W. (2011a). Theory and practice of citizenship education: the case of policy, science and education in the Netherlands. Revista de Educacion, 209-224.

Veugelers, W. (2011b). The moral and the political in global citizenship education: Appreciating differences in education. Globalisation, Societies and Education, 9(3-4), 473-485.

Veugelers, W. (2017a). The moral in Paulo Freire's educational work. Journal of Moral Education, 46, 412-421.

Veugelers, W. (2017b). Education for critical-democratic citizenship: Autonomy and social justice in a multicultural society. In N. Aloni, \& L. Weinrob (Eds.), Beyond bystanders: Educational leadership for a humane culture in a globalizing reality (pp. 47-59). Rotterdam, the Netherlands: Sense Publishers.

Veugelers, W. (2019a). Learning and teaching in critical-democratic education. Utrecht, the Netherlands: University of Humanistic Studies.

Veugelers, W. (Ed.). (2019b). Education for democratic intercultural citizenship. Leiden, the Netherlands: Brill/Sense.

Veugelers, W., De Groot, I., \& Stolk, V. (2017). Research for cult committee - Teaching common values in Europe. Brussels, Belgium: European Parliament, Policy Department for Structural and Cohesion Policy.

Westheimer, J., \& Kahne, J. (2004). What kind of citizen? The politics of educating for democracy. American Educational Research Journal, 41(2), 237-269.

Open Access This chapter is licensed under the terms of the Creative Commons Attribution-NonCommercial 4.0 International License (http://creativecommons.org/licenses/by-nc/4.0/), which permits any noncommercial use, sharing, adaptation, distribution and reproduction in any medium or format, as long as you give appropriate credit to the original author(s) and the source, provide a link to the Creative Commons license and indicate if changes were made.

The images or other third party material in this chapter are included in the chapter's Creative Commons license, unless indicated otherwise in a credit line to the material. If material is not included in the chapter's Creative Commons license and your intended use is not permitted by statutory regulation or exceeds the permitted use, you will need to obtain permission directly from the copyright holder. 